\author{
Hans Wiesmeth ${ }^{a)}$, Natalya V. Starodubets ${ }^{b)}$ \\ a) Technical University of Dresden, Dresden, Germany \\ a, b) Ural Federal University, Ekaterinburg, Russian Federation \\ b) https://orcid.org/0000-0001-8687-2050,e-mail: n.v.starodubets@gmail.com
}

\title{
The Management of Municipal Solid Waste in Compliance with Circular Economy Criteria: the Case of Russia ${ }^{1}$
}

In Russia, increasing amounts of municipal solid waste (MSW) accompanied by environmental degradation have recently led to changes in legislation. Their main goal is to reduce landfilling, to increase utilisation, to introduce the principle of extended producer responsibility (EPR). These are first steps towards a circular economy. The main purpose of the paper is to study how to improve the efficiency of Russian MSW management using circular economy criteria. The study relies on methods such as systemic analysis and synthesis, comparison and generalisation, stakeholder analysis. The detailed analysis of current MSW management system in Russia showed contradictions between its participants regarding the distribution of material waste streams and financing, which leads to difficulties in EPR principle implementation and to possible problems in achieving the goals of the entire MSW management system. According to its current design, recycling receives maximum government support, opposite to reuse and prevention of waste: companies involved in these activities are still outside the scope of MSW management system, and the authors recommend considering their legislative inclusion in it. The critical analysis of Russia's EPR design compared with EU experience showed problems such as low environmental fees, low utilisation standards and the lack of households' involvement, which makes EPR design inefficient. The current regulations may help divert some waste from landfills to utilisation and recycling, but beyond that the incentives do not yet correspond to those required for implementing the EPR principle and a circular economy. Consequently, the paper provides recommendations for amending this, which can be used by decision makers at the federal level to improve MSW management system and increase its efficiency.

Keywords: MSW management, circular economy, business models, waste hierarchy, waste prevention, waste utilisation, recycling, landfilling, incentive-compatible regulations, producer responsibility organisation (PRO), extended producer responsibility (EPR)

\section{Acknowledgments}

The work was supported by the Act 211 Government of the Russian Federation, contract № 02.A03.21.0006.

For citation: Wiesmeth H., Starodubets N.V. (2020). The Management of Municipal Solid Waste in Compliance with Circular Economy Criteria: the Case of Russia. Ekonomika regiona [Economy of region], 16(3), 725-738, https://doi.org/10.17059/ ekon.reg.2020-3-4

\footnotetext{
${ }^{1}$ (c) Wiesmeth H., Starodubets N. V. Text. 2020.
} 
ОРИГИНАЛЬНАЯ СТАТЬЯ

УДК: 338.23

\author{
Х. Висмет ${ }^{\text {a) }}$, Н. В. Стародубец б) \\ а) Дрезденский технический университет, Дрезден, Германия \\ а, б) Уральский федеральный университет, Екатеринбург, Российская Федерация \\ 6) https://orcid.org/0000-0001-8687-2050,e-mail: n.v.starodubets@gmail.com
}

\title{
Управление твердыми коммунальными отходами в соответствии с критериями экономики замкнутого цикла: на примере России
}

В России рост количества твердых коммунальных отходов (ТКО), сопровождающийся ухудшением состояния окружающей среды, стал причиной для недавних изменений в законодательстве. Их основная иель - сократить количество полигонов ТКО, увеличить объем переработки отходов, внедрить приниип расширенной ответственности производителя (РОП). Это первые шаги к экономике замкнутого ицкла. Основная цель статьи - изучить способы повышения эффективности управления ТКО в России с использованием критериев ицркулярной экономики. Исследование опирается на такие методь, как системный анализ и синтез, сравнение и обобщение, анализ стейкхолдеров. Детальный анализ действующей системы управления ТКО в России показал, что существуют противоречия между ее субъектами в отночении распределения материальных и финансовых потоков, что приводит к трудностям в реализации приниипа РОП и возможным проблемам в достижении иелей всей системы управления TКО. В настоящее время максимальную государственную поддержку получает мусоропереработка, в отличие от повторного использования и предотвращения образования отходов: компании, занимающиеся этой деятельностью, все еще находятся вне системы управления ТКО, и авторы рекомендуют рассмотреть возможность их законодательного включения в нее. Критический анализ РОП в России в сравнении с опытом ЕС выявил такие проблемы, как низкие экологические сборы, низкие стандарты утилизации отходов и недостаточное участие в системе домашних хозяйств, что делает РОП неэффективной. Действующее законодательство может способствовать направлению части отходов с полигонов на утилизацию и переработку, однако этого не достаточно для реализации приниипа РОП и перехода к ииркулярной экономике. Таким образом, в статье представлены рекомендации по корректировке ситуации, которые могут быть использованы для улучшения системы обращения с ТКО и повышения ее эфбективности лицами, принимающими решения на федеральном уровне.

Ключевые слова: управление ТКО, циркулярная экономика, бизнес-модели, иерархия способов обращения с отходами, предотвращение образования отходов, утилизация отходов, переработка отходов, захоронение отходов, законодательное стимулирование, оператор по обращению с отходами, расширенная ответственность производителя (РОП)

\section{Благодарность}

Работа поддержана Постановлением 211 Правительства РФ, договор № 02.A03.21.0006.

Для цитирования: Висмет Х., Стародубец Н. В. Управление твердыми коммунальными отходами в соответствии с критериями экономики замкнутого цикла: на примере России. Экономика региона, 2020, Т. 16, вып. 3, 725-738, https://doi.org/10.17059/ekon.reg.2020-3-4

\section{Introduction}

Russia is abundant with natural resources and its vast territory is offering sufficient possibilities to landfill and "hide" waste. Therefore, regarding any strategies to implement a circular economy, Russia can be categorised as a follower, as other countries with similar characteristics. Nevertheless, health concerns and rising environmental awareness in obviously growing part of the population make it necessary to develop more environmentally friendly and more efficient ways of waste management, to reduce the damaging effect of waste on the environment, probably to adopt the waste hierarchy, which is an important part of any circular economy.

The observations regarding the generation of municipal solid waste (MSW) in Russia are as in many other countries: with economic devel- opment waste is increasing, too. Moreover, certain types of waste, such as plastics, are growing faster than the economy. According to Larionov \& Ecorem, in the near future Russia likely needs to substantially increase its capacity to accommodate the growing volumes of waste [1, p.7], or to change its waste management strategy. Similarly, Larionov \& Ecorem [1], Korobova et al. [2] and Ermolaeva [3, 4] discuss further details regarding the current situation of waste management in Russia.

What to do in such a situation? Russia relies on the goal to "utilise" more waste, i.e., to recycle more of it, or to reuse it in some other way. For this purpose, the country modernised the waste management regulation, also strengthened the role of the EPR principle. However, the various regulations, which, optimally, should be linked in a way to support each other, are difficult to disentan- 
gle with not always clear responsibilities distributed between the federal, regional and local levels. There are also contradictions between the stakeholders in the waste management system related to the distribution of material waste streams and state financing.

Alternatively, the experience of other countries shows that the construction of a waste management system based on circular economy criteria can help overcome these contradictions.

Thus, the current paper studies how to improve the efficiency of the Russian MSW management system (reduce landfilling, increase recycling, reduce or prevent waste) using circular economy criteria. In practice, such a system requires business model construction in accordance with the waste hierarchy, the effective use of EPR, and incentive compatible regulation measures - all these issues are discussed in the paper.

\section{Theory}

This review of the literature introduces the concept of a circular economy and its connection with waste management through business models, waste hierarchy and the EPR principle. Thereafter there is a review of some of the international literature on waste management in Russia.

50 years ago, the concept of the circular economy slowly emerged from a growing number of noticeable discrepancies between economic growth and increasing environmental degradation. This happened in many parts of the world: in developing, emerging and industrialised countries, in market, transition and centrally planned economies - regardless of the political system.

Pearce and Turner introduced the concept of the circular economy, explaining "the fundamental ways in which consideration of environmental matters affects our economic thinking” [5, p. 29]. They focus on the main interactions between the environment and the economy: the environment as a direct source of utility, as a supplier of natural resources for production, and as receiver of waste, which could not be assimilated or recycled by nature itself. Heshmati [6] and Antikainen et al. [7], among others, provide further details on the history of "circularity" in economics and, especially, in environmental economics.

Ignoring the vital tasks of the environment over a time period depletes natural resources such as forests, unpolluted air and water, further complicated through uncontrolled landfilling of waste. The linear economy of the last centuries was based on the implicit assumption that the natural system, the environment, would continue to provide appropriate and necessary resources, and would assimilate all waste products, led to the air, water and soil pollution in the context of the industrialisation.

According to Pearce \& Turner [5], the academic concept of circular economy points to the inherently circular structure of an economic system with the circular economy fully respecting the interdependencies between the environment and economy and, even more importantly, sustainably preserving the fundamental functions of the environment. Similar to a traditional market economy, also a circular economy is substantially dependent on local economic and environmental conditions. In a practical context, the circular economy contrasts the traditional linear economy of "take - make - dispose" as explained by the Ellen MacArthur Foundation [8] and suggests "take make - reuse" economy. The circular economy has the following criteria:

- waste is used as raw material for the production of new goods;

- - components must be designed so that they can be processed with minimal energy and without loss of quality;

- use of renewable energy sources;

- it is more efficient to reuse goods, perform their maintenance and restoration, rather than recycle them and return them to the level of the component manufacturer;

- the need for a complex assessment considering economic, environmental, social factors.

Based on the main processes of the circular economy (they are maintenance, reuse of goods, refurbishment, remanufacturing, recycling, biochemical extraction, anaerobic digestion, composting) the following business-models can be created (according to Accenture ${ }^{1}$ and OECD [9]):

- Circular suppliers - replacing traditional material inputs derived from virgin resources with bio-based, renewable, or recovered materials, reduce demand for virgin resource extraction in the long run;

- Resources recovery - recycle waste into secondary raw materials, thereby diverting waste from final disposal while also displacing the extraction and processing of virgin natural resources;

- Sharing platforms - the sharing of under-utilised products, the reduction of the demand for new products and their embedded raw materials;

\footnotetext{
${ }^{1}$ Accenture. Circular Advantage. [Electronic source] https:// www.accenture.com/t20150523t053139__w_/us-en/_acnme$\mathrm{dia} /$ accenture/conversion-assets/dotcom/documents/global/ pdf/strategy_6/accenture-circular-advantage-innovative-business-models-technologies-value-growth.pdf (date of access: 20.04.2020).
} 
- Product life extension - extend the use period of existing products, slow the flow of constituent materials through the economy, and reduce the rate of resource extraction and waste generation;

- Product as a service - services rather than products are marketed, improve incentives for green product design and more efficient product use, thereby promoting a more sparing use of natural resources.

Circular economy criteria can help in building efficient MSW management system based on (1) high recycling rate, and what is more important, (2) MSW per capita reduction. This issue is discussed in many foreign studies, such as [1013] and others. Thus, Stahel [10] points out that "In a circular economy, the objective is to maximise the value at each point in a product's life". Genovese et al. [11] specify the role of sustainable supply chain management that helps create a "self-sustaining production systems in which materials are used over and over again" and reduce MSW per capita. Dumlao-Tan, Halog [12] focus on the significance of a circular economy to solid waste management and consider corresponding concepts and practises. In the study [13] authors present a conceptual approach that helps assess how complex value is created, destroyed and distributed in resource recovery from waste systems.

Many countries build their national waste management systems based on circular economy criteria (see e.g. the cases of EU, USA, Korea, Japan, China, and Vietnam discussed in [14]).

In waste management, the implementation of the circular economy criteria is reflected through a hierarchy of waste management methods. Van Ewijk and Stegemann [15], refer to the emergence of the concept of the waste hierarchy in the 1980s, prioritising reduction, recycling and reuse of hazardous waste over treatment or disposal (p. 123). The Waste Directive of the European Union (EU) of 2008 encourages the member states "to apply the waste hierarchy and, in accordance with the polluter-pay principle, a requirement that the costs of disposing of waste must be borne by the holder of waste, by previous holders or by the producers of the product from which the waste came". The Directive further formulates: "The following waste hierarchy shall apply as a priority order in waste prevention and management legislation and policy: (a) prevention; (b) preparing for reuse; (c) recycling; (d) other recovery, e.g. energy recovery; and (e) disposal".

The literature on the waste hierarchy and its implementation in practice includes Gharfalkar,
Campbell and Hillier [16] - authors analyze the waste hierarchy in the EU Waste Directive, complaining of a lack of clarity regarding the main concepts. Also, Pires and Martinho [17] propose a waste hierarchy index "to measure the waste hierarchy within a circular economy context, applied to municipal solid waste".

The implementation of the waste hierarchy is therefore an important part of circular economy strategies. It helps to prevent and reduce waste and thereby protects the assimilative capacity of the environment. The EPR principle is an important tool to implement the waste hierarchy (see Wiesmeth \& Häckl [18]).

The EPR principle places some responsibility for a product's end-of-life environmental impacts on the original producer and seller of that product (Walls [19]). This corresponds to the OECD's definition of EPR as an "an environmental policy approach in which a producer's responsibility for a product is extended to the post-consumer stage of a product's life cycle" (OECD [20], Walls [19]).

Whereas the polluter pays principle establishes a link between a polluting activity and environmental taxes or fees to reduce the polluting activity, the EPR principle constitutes a holistic approach: by focusing on a product's end-of-life environmental impacts, producers should be motivated to think about a "Design for Environment" (DfE), to make their products usable for a longer time, make them reusable and simpler to recycle, and, above all, reduce or prevent waste.

Implementing the EPR principle in order motivate producers for a DfE, requires some considerations. One of the main roads leading to a DfE is to "urge" producers to make appropriate use of their knowledge. This could, probably, best be achieved by making them pay for collecting and recycling the waste resulting from their products. This could indeed put some pressure on them to more than think about a DfE for their products.

This straightforward "holistic" idea contains some pitfalls, which need to be carefully discussed in the context of implementing a circular economy (see Wiesmeth \& Häckl [21]). Nevertheless, one of the crucial questions regarding an EPR policy in waste management has to refer to the organisation of the collection systems, probably including sorting plants, and recycling activities, not to forget financing these activities. The concept of "Integrated Waste Management", also of relevance for Russia's approach, is usually based on the EPR principle (see Bilitewski, Härdtle and Marek [22]).

The next issue refers to the question, how to organise the financial responsibilities regarding 
collection and recycling activities. As these activities do, in most cases, not count among the core business activities of the companies, it most often makes sense to outsource these activities to a third-party organisation, usually called a "Producer Responsibility Organisation" (PRO). Both BIO Intelligence Service [23] and OECD [24] provide surveys and reviews of this concept and its different manifestations.

Russian academic literature, however, lacks studies examining the ways of transforming exciting MSW management system using circular economy criteria, analyzing the stakeholder interaction in the waste management system, the business models in which they are involved, the EPR mechanism, and this aroused authors' interest in this topic. Current studies focus on such aspects of waste management improvement as: assessing the systems and business companies' engagement with collecting, sorting and recycling of waste, and giving recommendations for a transition to some features of a circular economy. Plastinina et al. [25] analyze the MSW management system, also the factors hindering the circular economy development. According to Larionov \& Ecorem, Russia needs to substantially increase its capacity to accommodate the growing volumes of waste [1, p. 7], and Larionov \& Ecorem [1], Korobova et al. [2] and Ermolaeva $[3,4]$ discuss further details regarding the current situation of waste management in Russia and its further development.

\section{Materials and Methods}

As the literature review showed, certain challenges are associated with the practical construction of a waste management system in accordance with circular economy criteria (including the application of the EPR principle in a practical context) and the lack of studies on ways to overcome these challenges in Russia.

In this regard, it is proposed to give a brief description of MSW management in Russia, including analysis of waste management methods' compliance with the waste hierarchy. After that, using stakeholder approach, authors are going to describe the interaction between the participants in the MSW management system and the contradictions that arise between them, to consider business models in which participants are involved and analyse them according to the circular economy criteria. It is also proposed to carry out a critical analysis of the existing EPR design, identify its shortcomings and, using accumulated experience of other countries, give recommendations for its improvement.
This study is therefore descriptive, however makes use of important economic principles for evaluating existing policies and "designing" appropriate environmental policies. The results allow various recommendations to improve the effectiveness of waste management for a better protection of health and the environment.

\section{Participants interaction within Russian MSW management framework and corresponding business models}

The situation regarding waste management in Russia is not different from that in many other countries: volumes of waste are increasing and the public authorities try controlling the development with an increasing number of regulatory measures.

About 55 million tonnes of MSW are currently generated in Russia per year. The volume continues to grow, with a growth rate of $14.4 \%$ from 2010 to 2018, and an average annual growth rate of $1.6 \%$. Moreover, the waste generated per capita is also growing: 12 \% from 2010 to 2018, and an annual growth rate of $1.4 \%$ (See Table 1 ). However, it should be mentioned here that with some $370 \mathrm{~kg}$ per inhabitant Russia is below the European Union (EU) with some $490 \mathrm{~kg}$ per inhabitant in $2018^{1}$, but the numbers keep increasing and will likely reach the levels in the EU.

Moreover, the numbers show that the prevailing method of waste management in Russia to date is landfill, less than $10 \%$ of the generated MSW is recycled.

In 2018, a share of $25 \%$ of MSW was generated in the 14 largest cities of Russia with a population above one million people (which is approximatively $22 \%$ of the Russian population).

Introducing the EPR principle in waste management requires the adequate integration of households and producers. A first step refers to access to separate collection facilities, which is now established in the larger Russian cities. Of course, this infrastructure may play a leading role in the effectiveness of separate waste collection (Shabanova [26]).

In 2019, Greenpeace's office in Russia compiled a rating on the availability of separate collection in cities with a population of more than 100,000 . The rating was based on data of more than 160 cities provided by the administration at the request of Greenpeace. ${ }^{2}$ The stationary containers availa-

\footnotetext{
${ }^{1}$ Eurostat. [Electronic source] https://ec.europa.eu/eurostat/ statistics-explained/index.php/Municipal_waste_statistics (Date of access: 01.03.2020).

${ }^{2}$ National Geographic Russia. The most convenient cities for MSW separate collection. [Electronic source] https://nat-geo.
} 
Table 1

Data on MSW in Russia, 2010-2017

\begin{tabular}{|l|c|c|c|c|c|c|c|c|c|}
\hline & 2010 & 2011 & 2012 & 2013 & 2014 & 2015 & 2016 & 2017 & 2018 \\
\hline $\begin{array}{l}\text { MSW generated, } \\
\text { mln tonnes }\end{array}$ & 47.1 & 48.2 & 51.2 & 52.2 & 52.6 & 53.3 & 53.8 & 54.8 & 53.9 \\
\hline $\begin{array}{l}\text { MSW generated, } \\
\text { kg per capita }\end{array}$ & 329.6 & 337.5 & 357.6 & 364.0 & 365.8 & 364.4 & 366.9 & 373.6 & 369.2 \\
\hline $\begin{array}{l}\text { MSW recycled, } \\
\text { mln tonnes }\end{array}$ & 6.42 & 4.86 & 5.38 & 4.92 & 4.26 & 4.16 & 4.78 & 5.58 & 6.00 \\
\hline
\end{tabular}

Source: State report "On the State of the Environment and Environmental Protection of the Russian Federation in 2018" (in: The Ministry of Natural Resources and Environment. State Report [Electronic source]. http://gosdoklad-ecology.ru/2018/\%20 (Date of access: 01.03.2020)).

Table 2

Target indicators for MSW management efficiency assessment (from the federal project "Formation of an Integrated MSW Management System")

\begin{tabular}{|l|c|c|c|c|c|c|c|}
\hline & $\mathbf{2 0 1 8}$ & $\mathbf{2 0 1 9}$ & $\mathbf{2 0 2 0}$ & $\mathbf{2 0 2 1}$ & $\mathbf{2 0 2 2}$ & $\mathbf{2 0 2 3}$ & $\mathbf{2 0 2 4}$ \\
\hline Share of MSW send to the utilisation in all MSW, \% & 3 & 7 & 16,2 & 22.8 & 24 & 33 & 36 \\
\hline Share of MSW send to the processing in all MSW, \% & 7 & 12 & 27 & 38 & 40 & 55 & 60 \\
\hline $\begin{array}{l}\text { Share of imported equipment for MSW processing } \\
\text { and utilisation, \% }\end{array}$ & 50 & 40 & 30 & 28 & 26 & 24 & 22 \\
\hline $\begin{array}{l}\text { Share of territorial MSW management schemes } \\
\text { in the form of electronic models among Russian } \\
\text { regions, \% }\end{array}$ & 20 & 50 & 100 & 100 & 100 & 100 & 100 \\
\hline
\end{tabular}

Source: Federal project "Formation of an Integrated MSW Management System" (in: Federal project "Formation of an Integrated MSW Management System" [Electronic source] https://bit.ly/30dJuRG (Date of access: 01.02.2020)).

ble to residents around the clock for at least one type of MSW were taken into account. The average ratio of the number of residents having access to stationary containers for separately collecting MSW to all city's residents turned out to be only $14.5 \%$.

The prevailing method of waste management in Russia to date is landfilling and by the 2010s many landfills had reached their capacity. This fact determined the logic of the ongoing reform in MSW management - to increase the percentage of recycled waste to reduce landfilling (Blokov [27]).

In Federal Law 89-FZ "About industrial waste and MSW", the priorities in the field of waste management were identified (in accordance with the waste hierarchy and circular economy principles): maximum use of raw materials; waste prevention; reduction of waste generation and reduction of waste hazard class in the sources of its generation; processing of waste (here it means mainly waste separation); waste utilisation; waste detoxification.

The important part of this waste hierarchy is "waste utilisation" - the use of waste for the production of goods (products), the performance of work, rendering of services, including reuse, re-

$\mathrm{ru} /$ planet/camye-udobnye-goroda-dlya-razdelnogo-sbora-musora/ (Date of access: 05.03.2020). use for its intended purpose (recycling), return after appropriate preparation to the production cycle, the utilisextraction of valuable components for their reuse (recovery).

Reform targets were also set (Table 2) by the federal project "Formation of an Integrated MSW Management System" (part of the national project "Ecology"). Observe that these targets explicitly refer to an "Integrated Waste Management System".

The targets focus on the least priority methods of waste management (processing and utilisation), and are, therefore, only loosely connected with the circular economy criteria. In particular, waste prevention does not play an important role. Simultaneousely, in 2024, when $60 \%$ of MSW should be processed, slightly more than half of this amount (36 \% MSW) should be utilised. Probably this situation is due to the fact that mixed, unsegregated waste must be processed, for which the rate of selection of secondary material resources is not high for technological reasons.

In general terms, the current scheme of interaction between participants in the field of MSW management is as follows (see Figure 1). The main stakeholders are:

- State authorities (federal, regional municipal level). At the state level, as a result of the reform, there is mainly a redistribution of actual activities related to MSW management from the mu- 


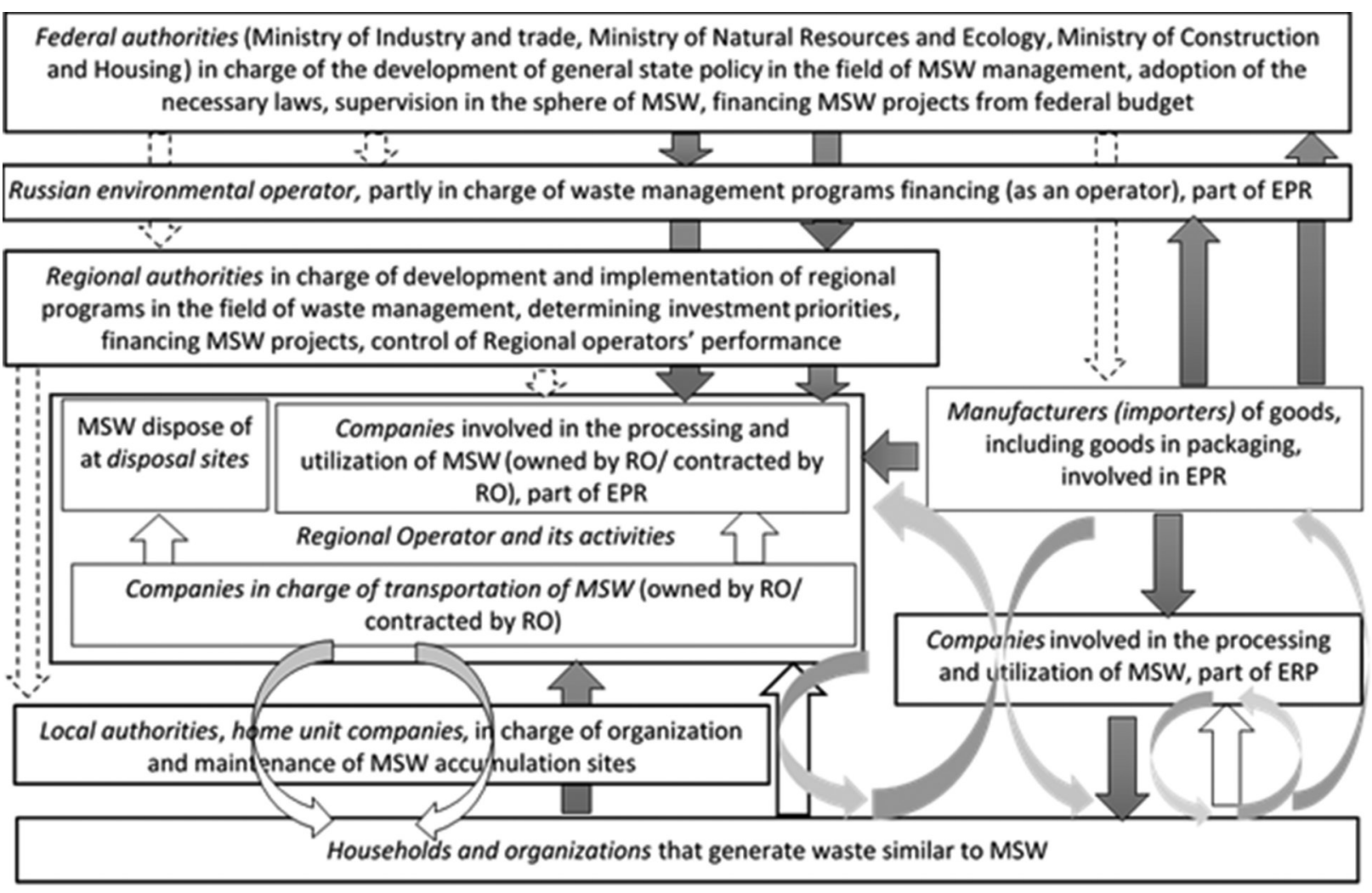

Fig. 1. Structure of the Russian MSW Management System Source: Own Drawing

nicipal to the regional level. The functions related to the development of general state policy in the field of MSW management, adoption of the necessary laws, and supervision in the sphere of MSW remains with the federal level.

The regions received authority in the development and implementation of regional programmes in the field of waste management, determining the priorities of investment activities in this area. Also, regions are now responsible for the appointment and performance of a special organisation, a regional operator in charge of waste management activities in this region.

At the municipal level, there remains a narrow range of issues related to the organisation and maintenance of MSW accumulation sites, with environmental education and the formation of ecological culture.

- Regional operator. A "Regional operator" constitutes a public or private organisation selected during a specially organised procedure at the level of each region. There can be one or more regional operators in each region depending on the amount of MSW generated. Regional operator - is an agent (manager of funds) between the consumer and the resource-supplying organisations (transport companies, landfills), its main task is to ensure the handling of MSW in the entrusted territory.
- Manufacturers (importers) of goods, including goods in packaging. They are part of the economic mechanism stipulated by the 89-FZ - Extended Producer Responsibility (EPR). These organisations, with the involvement of third-party organisations (regional operator, Russian environmental operator, industry associations), are obliged to process and utilise packaging and other consumer goods that lost their consumer properties. They thereby have to comply with the disposal standards or pay an environmental fee.

- The Russian environmental operator. This environmental operator is specially established by decree of the President of the Russian Federation and constitutes a public not-forprofit organisation. Its main goal is to form an integrated system for handling MSW, with the following tasks:

o Participation in the coordination of activities of the state authorities at all levels in implementing the legislative norms in the field of MSW management;

o Attracting private investors in the field of MSW management;

o Provision (organisation) of waste utilisation within the EPR by agreement with manufacturers/ importers;

o The knowledge base of the further development in the field of MSW management, and the 
implementation of voluntary certification of technologies in this sphere;

o The mplementation of scientific activities in the field of MSW management.

- Companies collecting, accumulating, transporting, disposing MSW under an agreement with a regional operator. Often, a regional operator does not have the necessary capacities to perform the above activities, so it can hire subcontracting organisations.

- Companies involved in the processing and utilisation of MSW. On the one hand, there are companies that have relations with regional operators (may be owned by the regional operator) and whose production facilities centrally receive unsorted waste collected by the regional operator. However, the processing and utilisation capabilities of such companies are limited. For example, in 2018, 1.8 million tonnes of MSW were generated in the Sverdlovsk Region (with a population of 4.3 million), 216 thousand tonnes were processed centrally by such companies, 178 thousand tonnes were utilised (according to the territorial scheme of the Sverdlovsk Region ${ }^{1}$ ).

On the other hand, since the private business has a market interest in doing this kind of activity, there are private companies that collect, transport, process and utilise MSW at their own production facilities. Thus, in cities with a large volume of MSW generation, such companies are numerous.

This type of activity attracts private business, but the situation can change. According to the logic of the reform in the MSW sector, it is planned to establish, using both private and public investments, large inter-territorial complexes for the processing and utilisation of unsorted MSW, which, in order to return the invested funds, will be interested in stable high volumes of unsorted waste. It is likely that this will complicate the activities of small private companies (for example, a ban on the placement of containers of private companies at MSW accumulation sites, etc.). This can lead to the centralisation of MSW flows for processing.

- Households and organisations that generate waste similar to MSW. Owners of MSW must conclude an agreement with a regional operator for the provision of services for the MSW management. These services are provided in accordance with the approved tariff, which is calculated based on MSW generation standards (m3 per per-

\footnotetext{
1 Territorial scheme of the Sverdlovsk Region in the sphere of waste (including MSW) management. [Electronic source] https://bit.ly/382Q7Jt (Date of access: 01.03.2020).
}

son) and does not depend on the actual volume of waste generation.

Thus, the regulations contain all requirements for an integrated waste management system based on the EPR principle: there is a reference to the waste hierarchy, there are efforts to make manufacturers responsible for the waste by using EPR principle, and there are organisations, which resemble "Producer Responsibility Organisations" (PROs). Moreover, the regulations address all relevant stakeholders in waste management, also an important requirement for a holistic policy such as "Integrated Waste Management".

Nevertheless, it is various parts, the various policy tools, have to be appropriately linked to achieve the goals (see Wiesmeth and Häckl [21]).

The Russian MSW management framework with all stakeholders, their functions and interaction between them within regulation tools is presented in Figure 1, where financial flows are shown by grey arrows, material flows (MSW) by white arrows, the regulatory impact is shown by dashed arrows.

The findings from MSW management framework are following. The households and organisations are the main and only source of MSW, and they can significantly increase the utilisation rate, if they participate in the separate waste collection. For this purpose, they should be included in understandable feedback loops, implying perceived economic and environmental benefits from waste sorting.

In the framework, there is only one explicit loop - between households and companies involved in the processing and utilisation of MSW, which is not efficient because only a small part of MSW (mainly furniture, batteries, tyres, household appliances, etc.) goes to these companies. The bulk of MSW is accumulated at container sites and then the regional operator is in charge of them.

Another loop is possible in the current EPR design - between households and companies involved in the processing and utilisation of MSW, and manufacturers (importers) of goods. Most likely, this loop will be legally abolished because there is no need for a "bifurcation" of material flows of MSW. Such changes to the EPR policy are currently being discussed at the government level.

Another loop is between households, regional operators and manufacturers (importers) of goods within the EPR system. However there is a problem of cross-financing: for the same service "MSW handling” regional operators will get financing from both households and from manufacturers (importers) of goods within the EPR system. 
MSW Management System's stakeholders involvement in the circular economy (CE) business models

\begin{tabular}{|l|l|l|l|}
\hline $\begin{array}{c}\text { CE business } \\
\text { model (According } \\
\text { to Accenture) }\end{array}$ & \multicolumn{1}{|c|}{$\begin{array}{c}\text { Business model } \\
\text { availability }\end{array}$} & \multicolumn{1}{|c|}{ Stakeholders interconnection } & \multicolumn{1}{c|}{$\begin{array}{c}\text { Government } \\
\text { stimulation }\end{array}$} \\
\hline Circular suppliers & $\begin{array}{l}\text { Available, within } \\
\text { existing MSW } \\
\text { Management System }\end{array}$ & $\begin{array}{l}\text { Households provide (sell) MSW to the } \\
\text { companies involved in the processing and } \\
\text { utilisation of MSW, producing finished products } \\
\text { from waste (also packaging within EPR) }\end{array}$ & $\begin{array}{l}\text { Economic incentive is } \\
\text { possible within national } \\
\text { project "Ecology" }\end{array}$ \\
\hline Resources recovery & $\begin{array}{l}\text { Available, within } \\
\text { existing MSW } \\
\text { Management System }\end{array}$ & $\begin{array}{l}\text { Households provide (sell) MSW to the } \\
\text { companies involved in the processing and } \\
\text { utilisation of MSW, producing semifinished } \\
\text { products from waste (PVC beads, PVC flakes, } \\
\text { non-ferrous and ferrous scrap etc.) }\end{array}$ & $\begin{array}{l}\text { Economic incentive is } \\
\text { possible within national } \\
\text { project "Ecology" }\end{array}$ \\
\hline Sharing platforms & $\begin{array}{l}\text { Available, but not } \\
\text { within existing, } \\
\text { enshrined in law MSW } \\
\text { Management System }\end{array}$ & $\begin{array}{l}\text { Households share products using sharing } \\
\text { platforms (Bla-bla car, Airbnb, carsharing, } \\
\text { Next2you etc.), sharing instead of buying }\end{array}$ & $\begin{array}{l}\text { Economic incentive is } \\
\text { not provided }\end{array}$ \\
\hline $\begin{array}{l}\text { Product life } \\
\text { extension }\end{array}$ & $\begin{array}{l}\text { Available, but not } \\
\text { within existing, } \\
\text { enshrined in law MSW } \\
\text { Management System }\end{array}$ & $\begin{array}{l}\text { Households apply for a service of product life } \\
\text { extension to customer services, repair shops. } \\
\text { Also sell used goods to other households via } \\
\text { special platforms (E-Bay, Amazon etc.) }\end{array}$ & $\begin{array}{l}\text { Economic incentive is } \\
\text { not provided }\end{array}$ \\
\hline $\begin{array}{l}\text { Available, but not } \\
\text { within existing, } \\
\text { enshrined in law MSW } \\
\text { Management System }\end{array}$ & $\begin{array}{l}\text { Households turn to companies to receive service } \\
\text { instead of receiving goods (taxi, rent of major } \\
\text { appliances, etc.) }\end{array}$ & $\begin{array}{l}\text { Economic incentive is } \\
\text { not provided }\end{array}$ \\
\hline
\end{tabular}

And finally, one loop that is not yet designed (the white one), which is between households and regional operators. Now households are involved in one-way economic relations with regional operators, the lack of a clear feedback makes households marginally involved in the waste management system and this, along with insufficient information on the progress of the reform, is a probable reason for the low collection of MSW handling payments. To date, the collection rate is approximatively $50 \%$. The introduction of economic benefit from a separate waste collection (it may be MSW handling payment reduction, if a household is involved in separate collection) will increase households' involvement in the MSW management system, increase waste utilisation rate, and may also lead to waste prevention.

According to Figure 1, there is a conflict of interests between companies involved in the processing and utilisation of MSW and regional operators. Now they both are interested in getting MSW material flows. But it seems that in the future the government will rely on regional operators and related companies, in the allocation of funding for the implementation of MSW management projects, because this significantly reduces investment risks. The revenue of regional operators is guaranteed by the constant receipt of payments from the households, and MSW material flows for processing and utilisation is also certain.
As for the connection with the circular economy criteria - the existing Russia's MSW management framework is aimed to increase the percentage of recycled MSW (in line with national MSW management targets), and hardly contributes to reducing per capita MSW generation and waste prevention.

For a better understanding of how the stakeholders interact with each other, authors analyze their involvement in the circular economy business models, described in the theory section, and the role of the state in stimulating the development of these business models (Table 3).

The analysis of circular economy business models and the possibility of their application in the field of MSW management showed the following.

1. The analyzed business models contribute to the achievement of the MSW management system goals. At the same time, such models as "circular suppliers" and "resources recovery" help to increase recycling rate, while "sharing platforms", "product life extension", "product as a service" contribute to the rational consumption and MSW per capita reduction.

2. It should be noted that in Russia all the considered business models are implemented, and "sharing platforms", "product life extension", "product as a service" show substantial growth over recent years, they contain significant potential. According to [28], Russia's sharing market 
in 2018 was valued at 511 billion rubles (around 7 billion euros). In other words, a quarter of all Russian e-commerce, and experts believe that this trend will continue.

3. At the same time, enshrined in law MSW Management System provides for the implementation and state financing only within the framework of such business models as "circular suppliers" and "resources recovery". "Sharing platforms", "product life extension", "product as a service" are outside the existing state MSW management framework, which limits the implementation of circular economy criteria in this area and reduces MSW management's efficiency.

Thus, if building MSW management system in accordance with circular economy criteria, considering the waste hierarchy, the government should study the possibility of including entities such as customer services, repair shops, sharing platforms, companies, marketing product as service in the MSW management framework and provide their stimulation within federal project "Ecology". This will increase the efficiency of the waste management system and will help to reduce the MSW per capita.

Authors also want to highlight the important role of EPR for the efficient operation of such business models as "circular suppliers" and "resources recovery". A critical analysis of the existing Russia's EPR design, as well as suggestions for its improvement will be presented in the next section.

\section{Critical Analysis of EPR Principle Practice}

In the Russian legislation the EPR principle is interpreted in the following way: all manufacturers and importers of goods that are to be utilised after they have lost their consumer properties, including packaging (regulated by the list, see Table 4), must ensure their utilisation in accordance with the established target (Table 4 ) in one of the following ways:

- independently, by organising their own infrastructure for collection, processing, utilisation of waste from the use of goods;

- by concluding a direct contract with the appropriate organisation involved in the collection, processing, and utilisation of waste (this organisation may be a regional operator);

- by creating an association (union) of manufacturers, importers of goods, which on behalf of companies would recycle issues (for example, the Russian environmental operator could act as such an organisation).

If the utilisation standard is not fulfilled, the organisation pays an environmental fee. The fee goes to the federal budget and is spent through the implementation of state programs in the form of subsidies to the regions for co-financing activities of regional programmess in the field of waste management. Subsidies are given, as a matter of priority, for fulfilling waste utilisation standards under the EPR by those producers and importers who paid the environmental fee, in particular for the creation of waste processing and utilisation facilities. According to the Ministry of Natural Resources and Ecology, 1.344 billion rubles (16.8 mln Euro) were paid in 2016, almost 2.6 billion rubles (32.5 mln Euro) in 2017, and 2.2 billion rubles in 2018 (27.5 mln Euro) as environmental fee ${ }^{1}$.

Assessment: There is a basic issue with this structure: the fact that companies may set up their own infrastructure for utilising waste products may lead to vested interests. If, for example, recycling of PET bottles is profitable, such a company might be induced to increase the share of drinks in plastic bottles, thereby increasing plastic waste ending up in the environment. A similar consideration holds for associations. Thus, it is necessary to separate regular production decisions (mineral water) from environmental decisions (handling packaging waste). Wiesmeth and Häckl $[18,21]$ discuss this issue in more detail.

Immediately debatable are further the following provisions of the EPR. Firstly, many experts, including associations of MSW recyclers, point out that the rates of the environmental fees are too low to cover the costs of preparing waste for recycling. For example, in order to organise separate accumulation, collection, sorting, compression and delivery to the processor 1 ton of PET, 15-16 thousand rubles are needed, not including the cost of the recycling process itself. However, the rate of environmental fee is 3.8 thousand rubles per ton of such kind of waste.

According to the Waste Paper Recyclers League, the same situation regarding the rate of the environmental fee holds for waste paper. The rate of the environmental fee is 2.4 thousand rubles per ton and is not sufficient to cover the cost of waste paper preparing for utilisation in the European part of the country, where $80 \%$ of waste paper is generated (the cost of preparing a waste paper for utilisation in this region is about 3.0 thousand rubles per ton).

Assessment: The conclusion and recommendation in this case is that the costs of collecting and recycling waste should be left to a competitive

\footnotetext{
${ }^{1}$ Russian News Agency. The Ministry of Natural Resources proposed to bring the packaging processing rate to $100 \%$ [Electronic source] https://tass.ru/nacionalnye-proekty/6774613 (Date of access: 01.03.2020)
} 
Table 4

Some goods to be utilised according to the EPR principle, the standards for utilisation and environmental fee rates

\begin{tabular}{|l|c|c|c|}
\hline \multirow{2}{*}{ Name of a product group } & Utilisation standards, \% & \multirow{2}{*}{$\begin{array}{c}\text { Environmental fee, } \\
\text { rubles per } \mathbf{1} \text { ton }\end{array}$} \\
\cline { 2 - 3 } & $\mathbf{2 0 1 8}$ & $\mathbf{2 0 1 9}$ & 11,791 \\
\hline Clothes and accessories & 0 & 5 & 2,378 \\
\hline Corrugated paper and cardboard, packaging made of it & 25 & 35 & 2,378 \\
\hline Other packaging made of paper and cardboard & 10 & 15 & 3,844 \\
\hline Plastic Packaging & 10 & 15 & 26,469 \\
\hline Computers and peripherals, office equipment & 5 & 10 & 26,469 \\
\hline Monitors, television receivers & 5 & 10 & 26,469 \\
\hline Household electronic equipment & 5 & 10 & 2,423 \\
\hline Packing from metal and aluminium & 10 & 15 & 3,844 \\
\hline Polymer packaging & 10 & 15 & 2,378 \\
\hline Corrugated cardboard packaging & 25 & 35 & 2,378 \\
\hline Packaging made of paper and corrugated cardboard & 10 & 15 & 2,564 \\
\hline Glass packaging & 15 & 20 & \\
\hline
\end{tabular}

Source: The Government Decree from 28.12.2017 № 2971-r, The Government Decree from 09.04.2016 № 284.

process. Producer Responsibility Organisations (PROs), which are independent from manufacturers, offer fees for these activities and manufacturers have to join one of these PROs and license their packaging (see again Wiesmeth and Häckl $[18,21]$ for more details).

Secondly, environmental collection funds, according to the requirements of 89-FZ, are collected centrally in the federal budget and can be used to finance the construction of waste treatment and utilisation facilities, bypassing the financing of separate collection infrastructure, which increases the cost of preparing waste for utilisation and reduces its effectiveness. It is also not entirely clear how the targeted spending of the environmental fee on the organisation of processing and utilisation of a specific type of waste from a specific producer/importer will be performed - after all, all the funds go to the "common pool".

Assessment: Whenever such an important structural component is not clearly understandable, then there will be all kinds of efforts to circumvent this regulation or to exploit with some other activities.

Thirdly, in regulatory documents, there are insufficient details regarding the types of packaging. For example, the group of products "polymer-packaging" with the utilisation standard of $15 \%$ and the environmental fee of 3.8 thousand rubles per tonne (see Table 4) includes various types of plastic packaging as PET, PVC, HDPE, LDPE, PP, PS, and others. It is absolutely clear that the utilisation possibilities and its cost for all types of plastic packaging are completely different (for example, you can compare PET and PP, which are well collected and recycled, and PS and other types of plastic packaging that can hardly be recycled). Thus, a producer of goods has the opportu- nity to reduce production costs by using cheaper non-recyclable plastic for packaging of lower quality, while the standard for recycling and the environmental fee rate for him will be the same as for the manufacturer who chose a more expensive recyclable plastic. Accordingly, the utilisation standard and rates of environmental fees should be differentiated depending on the specific type of packaging and the possibilities for its utilisation.

Assessment: Again, this task of setting appropriate prices for plastic packaging, for example, should be left to a competitive system of PROs. Manufacturers have to join on these PROs and pay license fees. It should be left to the PRO, whether there are different prices for different kind of plastic.

Fourth, it is unclear how to ensure efficient collection of waste from the use of goods if there is no deposit-paid institution and households are not involved in the process of separate waste collection through financial instruments (differentiated tariff).

Assessment: That's about the careful integration of households. There need to be appropriate technologies, waste bins etc. to motivate households to separate waste segregation. As the participation of households depends on environmental awareness, it is necessary to educate children, to establish waste segregation as a "social norm".

Moreover, many experts note the initially low utilisation standards, which can lead to underloading of the processing and utilisation capacities created within EPR.

Currently, there is an active discussion by state authorities with the participation of representatives of enterprises operating in the field of waste management regarding possibilities for increasing the efficiency of the application of the EPR prin- 
ciple. In particular, it is proposed to increase the standards for the utilisation of waste up to $100 \%$, to increase the amount of the environmental fees collected, supposedly to 136 billion RUB (1.7 billion Euros) per year.

It is also proposed to exclude the possibility of fulfilling utilisation standards through the conclusion of a direct contract with organisations involved in the collection, treatment, and utilisation of waste. This method is often used as a formal way of fulfilling responsibility under the EPR, but in fact, recycling is not carried out.

Among other things, the creation of a recycling fund is proposed, in which the environmental fees will be accumulated (instead of Federal budget) and then spent on the recycling of waste. The management of this fund will be performed by the Russian environmental operator.

Assessment: Raising these standards is important and the government needs to introduce an adequate process. This is not always an easy thing to do, and if private organisations are to be involved, then their activities need to be monitored.

\section{Results and discussion}

The analysis of the Russian MSW management system and its compliance with the circular economy criteria allows to draw the following conclusions. Contradictions remain between the participants of MSW management system regarding the distribution of material waste streams and financing, which leads to difficulties in EPR principle implementation and to possible problems in achieving the goals of the entire MSW management system. According to its current design, such waste management method as recycling receives maximum government support, which cannot be said about reuse and prevention of waste. Companies involved in these activities are still outside the scope of MSW management system, and authors recommend considering their legislative inclusion in it.

As indicated in Section 5, an EPR system depends on the linkages between various parts of waste management. Thus, high collection rates for some kinds of waste, packaging waste, for example, are required in order to raise costs for producers for collection and recycling and to motivate them for a DfE and to reduce or prevent waste. Therefore, consumers as "owners" of waste have to be integrated in the policy. Moreover, producers must have an environmentally reasonable possibility to reduce their individual costs for collection and recycling.

These basic requirements are not adequately taken into account in the current EPR regulations in Russia. There are some activities regarding a separate collection in various larger cities, but the compliance of the households as owners of waste remains unclear. Not much is known about efforts to increase collection rates.

Then, as outlined above, there seem to be no incentives at all to reduce waste. To the contrary, some stakeholders are encouraged to increase the waste to be recycled. The fact that such incentives are also, to some extent, contained in EPR systems in other countries, the EU, for example, does not justify this misspecification of the policy.

Are there possibilities for producers to reduce their payments for collection and recycling? If the environmental fees depend on the amount of waste, which is generated by a particular producer, then yes, of course. It may, however, be that the environmental fee is simply too low to think about a DfE and/or waste prevention.

The participation in an association or any other form of a PRO may lead to additional incentive issues with consequences for the environmental effectiveness of the EPR policy. Some hints about the necessity of having a system of independent PROs in competition are given in Section 5.2. These aspects are discussed and investigated in Wiesmeth \& Häckl [18,21].

Thus, there is the need to learn from these first steps and to further develop the EPR system in order arrive the implementation of the waste hierarchy, which is an important part of any strategy for developing a circular economy.

\section{References}

1. Larionov, A. \& Ecorem, N. V. (2012). MSW management: opportunities for Russia. Summary of key findings. Washington D.C.: IFC, World Bank Group [Electronic source] https://www.ifc.org/wps/wcm/connect/topics_ext_content/ifc_external_corporate_site/sustainability-at-ifc/publications/publications_report_russia-solidwaste (Date of access: 10.12.2019).

2. Korobova, N., Larionov, A., Michelsen, J. D., Pulyayev, M., Ivanovskyy, S., Turilova, K. \& Kuznetsova, M. (2014). Waste in Russia: garbage or valuable resource. Washington D.C.: IFC, World Bank Group [Electronic source] http://documents. worldbank.org/curated/en/702251549554831489/pdf/Waste-in-Russia-Garbage-or-Valuable-Resource.pdf (Date of access: 01.12.2019).

3. Ermolaeva, Y. V. (2018). Problems of institutionalization of waste management in Russia. Revista Amazonia Investiga, 7, 261-266. 
4. Ermolaeva, Y. V. (2019). Problems of modernization of the waste management sector in Russia: expert opinions. Revista Tecnologia e Societade, 15, 56-77.

5. Pearce, D. W. \& Turner, R. K. (1989). Economics of natural resources and the environment. Baltimore: The Johns Hopkins University Press, 243.

6. Heshmati, A. (2015). A review of the circular economy and its implementation. IZA Discussion Papers No. 9611. [Electronic source] http://ftp.iza.org/dp9611.pdf ((Date of access: 01.12.2019).

7. Antikainen, R., Lazarevic, D. \& Seppälä, J. (2018) Circular economy: origins and future orientations. Lehmann H (ed.) Factor X. Eco-efficiency in industry and science, 32, 115-129. doi: https://doi.org/10.1007/978-3-319-50079-9_7

8. Ellen MacArthur Foundation (2017). Circular economy and curriculum development in higher education. [Electronic source] https://www.ellenmacarthurfoundation.org/assets/downloads/EMF_HE-Curriculum-Brochure-03.10.17.pdf (Date of access: 01.12.2019).

9. OECD. Business Models for the Circular Economy: Opportunities and Challenges from a Policy Perspective (2018). Paris: OECD Publishing, 12.

10. Stahel, W. R. (2016). The circular economy. Nature, 531 (7595), 435-438.

11. Genovese, A, Acquaye, A. A., Figueroa, A., Koh, S. C. L. (2015). Sustainable supply chain management and the transition towards a circular economy: evidence and some applications. Omega, 66, 344-357.

12. Dumlao-Tan, M.I., Halog, A. (2017) Moving Towards a Circular Economy in Solid Waste Management: Concepts and Practices. In: Goel S. (eds) Advances in Solid and Hazardous Waste Management. Springer.

13. Iacovidou, E., Millward-Hopkins, J., Busch, J., Purnell, P., Velis, C. A., Hahladakis, J. N., ... \& Brown, A. (2017). A pathway to circular economy: Developing a conceptual framework for complex value assessment of resources recovered from waste. Journal of Cleaner Production, 168, 1279-1288.

14. Sakai, SI, Yoshida, H., Hirai, Y., Asari, M ., Takigami, H., Takahashi, S., ... \& Douvan, AR (2011). International comparative study of 3R and waste management policy developments. Journal of Material Cycles and Waste Management, 13 (2), 86-102.

15. Van Ewijk, S., \& Stegemann, J. A. (2016). Limitations of the waste hierarchy for achieving absolute reductions in material throughput. Absolute Reductions in Material Throughput, Energy Use and Emissions, 132, 122-128. https://doi. org/10.1016/j.jclepro.2014.11.051.

16. Gharfalkar, M., Court, R., Campbell, C., Ali, Z., \& Hillier, G. (2015). Analysis of waste hierarchy in the European waste directive 2008/98/EC. Waste Management, 39, 305-313. https://doi.org/10.1016/j.wasman.2015.02.007

17. Pires, A., \& Martinho, G. (2019). Waste hierarchy index for circular economy in waste management. Waste Management, 95, 298-305. https://doi.org/10.1016/j.wasman.2019.06.014.

18. Wiesmeth, H. \& Häckl, D. (2011). How to successfully implement Extended Producer Responsibility: considerations from an economic point of view. Waste Management \& Research, 29, 891-901. doi: https://doi.org/10.1177/0734242X11413333.

19. Walls, M. (2006). Extended producer responsibility and product design: economic theory and selected case studies. Discussion Paper, Resources for the Future, Washington DC. [Electronic source] http://ideas.repec.org/p/rff/dpaper/dp-0608.html. (Date of access: 24.11.2019).

20. OECD. Extended Producer Responsibility: A Guidance Manual for Governments (2001). Paris: OECD Publishing, 164. https://doi.org/10.1787/9789264189867-en.

21. Wiesmeth, H. \& Häckl, D. (2016). Integrated environmental policy: a review of economic analysis. Waste Management \& Research, 35, 332-345. doi: https://doi.org/10.1177/0734242X16672319.

22. Bilitewski, B., Härdtle, G., \& Marek, K. (1997). Waste Management. Berlin Heidelberg: Springer-Verlag. https://doi. org/10.1007/978-3-662-03382-1

23. BIO Intelligence Service. Review of the scope of the Directive 2012/19/EU on Waste Electrical and Electronic Equipment (WEEE). Final Report prepared for the European Commission - DG Environment (2014). Paris: BIO Intelligence Service, 116.

24. OECD. Extended producer responsibility: updated guidance for efficient waste management (2016). Paris: OECD Publishing, 292. https://doi.org/10.1787/9789264256385-en.

25. Plastinina, I., Teslyuk, L., Dukmasova, N. \& Pikalova, E. (2019). Implementation of circular economy principles in regional solid waste management: the case of Sverdlovskaya Oblast (Russian Federation). Resources, 8(2), 90. doi: https:// doi.org/10.3390/resources8020090.

26. Shabanova, M. A. (2019) Separate Waste Collection in Russia: the Level, Factors and Potential for Citizen Engagement. Mir Rossii, 28(3), 88-112.

27. Blokov, I. P. Okruzhayushchaya sreda i yeyo okhrana v Rossii. Izmeneniya za 25 let. Moscow: Sovet Grinpis, 422.

28. Gubnitsyn, A. The evolution of sharing services in Russia: on the road towards the circular economy model. AEB Business Quarterly, winter 2019/2020, 12-14.

\section{About the authors}

Hans Wiesmeth - Professor of Economics, Faculty of Business and Economics, Technical University of Dresden; Graduate School of Economics and Management, Ural Federal University (01062 Dresden, Germany; 19 Mira St., 620002 Ekaterinburg, Russian Federation) 
Natalia V. Starodubets - PhD in Economics, Assistant Professor, Ural Federal University; https://orcid.org/0000-00018687-2050 (19, Mira St., Ekaterinburg, 620002; e-mail: n.v.starodubets@gmail.com).

\section{Информация об авторах}

Висмет Ханс - профессор, факультет бизнеса и экономики, Дрезденский технический университет; Школа экономики и менеджмента, Уральский федеральный университет (Германия, 01062, г. Дрезден; Российская Федерация, 620002, г. Екатеринбург, ул. Мира, д. 19)

Стародубец Наталья Владимировна - кандидат экономических наук, доцент, Уральский федеральный университет; https://orcid.org/0000-0001-8687-2050 (Российская Федерация, 620002, г. Екатеринбург, ул. Мира, д. 19; e-mail: n.v.starodubets@gmail.com).

Дата поступления рукописи: 20.12.2020.

Прошла рецензирование: 01.02.2020.

Принято решение о публикации: 10.06.2020. 